\title{
First report of Alvania scuderii Villari, 2017 (Gastropoda: Mollusca) from Tyrrhenian Sea: Some biogeographic implications
}

\section{Walter RENDA ${ }^{1}$, Salvatore GIACOBBE ${ }^{2}$}

Cite this article as:

Renda, W., Giacobbe, S. (2021). First report Alvania scuderii Villari, 2017 (Gastropoda: Mollusca) from Tyrrhenian Sea: Some biogeographic implications. Aquatic Research, 4(2), 208-213. https://doi.org/10.3153/AR21016

${ }^{1}$ Via Bologna 18/A, 87032 Amantea (CS), Italy

${ }^{2}$ Messina University, Department ChiBioFarAm, Viale Stagno D’Alcontres, 98166 Messina, Italy

ORCID IDs of the author(s): W.R. 0000-0003-3944-6758 S. G. $0000-0002-4619-4862$

Submitted: 22.10 .2020

Revision requested: 08.12 .2020

Last revision received: 10.12 .2020

Accepted: 12.12 .2020

Published online: 28.03 .2021

Correspondence:

Walter RENDA

E-mail: w.renda1@tin.it

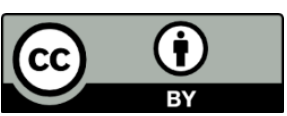

(C) 2021 The Author(s)

Available online at

http://aquatres.scientificwebjournals.com

\begin{abstract}
The cryptic gastropod Alvania scuderii Villari, 2017, recently described from the Strait of Messina as new species inside the $A$. scabra (Philippi, 1844) group, was known by restricted areas of eastern and southern Sicily. Some records from the type locality and south-eastern Tyrrhenian sea, which provided new data on habitat and bathymetric range, also enlarged northward, in a further basin, the known areal. Such areal, that overlaps a Mediterranean western-eastern biogeographic boundary, may be considered a further clue of an hydrological front that is responsible of a WestMediterranean footprint more marked than in nearby North-westernmost areas.
\end{abstract}

Keywords: Motile fauna, Hard bottom, Rissoidae, Alvania, Biogeography, Mediterranean sea 


\section{Introduction}

The recently described Alvania scuderii Villari, 2017, is a cryptic gastropod species belonging to the taxonomically problematic A. scabra (Philippi, 1844) group (Villari, 2017; Villari \& Scuderi, 2017). The new species, described on specimens from the Strait of Messina was initially related to "a peculiar sciaphilous environment of the Eastern Sicilian coasts", before other living specimens from S. Giovanni Li Cuti, near Catania, expanded the known habitat about $100 \mathrm{~km}$ to the south (Amati et al., 2020). Shells from Scilla testified the occurrence of A. scabra in the other side of the Messina Strait, whilst dead specimens from some localities of Linosa Island (Amati et al., 2020; Scaperotta et al., 2019) indicated a wider distribution which included the Strait of Sicily.

The present report of living specimens both from type locality and southern Tyrrhenian Sea, further expanding the known areal of this poorly known species, suggests some considerations about the western-eastern Mediterranean boundary line.

\section{Material and Methods}

Samples of motile macrofauna have been collected from the Strait of Messina and nearby localities of southern Tyrrhenian sea, in the framework of different research programs (MeBE; NIRS) Two sampling techniques have been employed, according to the main purposes of each investigation. In particular, qualitative samples have been collected by brushing of vegetated hard substrata, 1-4 $\mathrm{m}$ depth, while quantitative sampling have been carried out by scraping of $20 \times 20 \mathrm{~cm}$ hard bottom surface at 3-6 m, 12-16 m and 24-32 m depth. Samples have been washed on a $0.5 \mathrm{~mm}$ mesh sieve and the retained rapidly fixed in $70 \%$ ethanol. Mollusc fauna was sorted under stereomicroscope and specimens determined at the species level, as far as possible. Most species were photographed under stereomicroscope.

\section{ACRONYMS}

BEL: Benthic Ecology Laboratory, Messina University, Italy.

CWR: Collection Walter Renda, Amantea, Cosenza, Italy

MeBE: The Strait of Messina Benthic Ecosystem Project

NIRS: Ecology and Spatial Dynamics of Marine Not Indigenous and Rare Species Project

\section{Results and Discussion}

Samplings carried out in the type locality, Cape Peloro, altogether provided $32 \mathrm{~A}$. scuderii living specimens, all collected from the sheltered side of breakwater artificial reefs, 1-4 m depth, located at $38^{\circ} 15^{\prime} 43^{\prime \prime} \mathrm{N}-15^{\circ} 38^{\prime} 20^{\prime \prime} \mathrm{E}$ (two specimens, repository code: BEL147Faro2019As1-5), and 38 $8^{\circ} 15^{\prime} 35^{\prime \prime} \mathrm{N} \quad-$ $15^{\circ} 37^{\prime} 44^{\prime \prime} \mathrm{E}, 200 \mathrm{~m}$ northward (22 specimens, repository codes: BEL147Gran2019As1-17 and CWR1473121B1-5). In both sites, the sampled vertical surface was characterized by a dense algal covering, dominated by fleshy red algae under a brown algae canopy.

The other five specimens (BEL147Spez2019As6-10) were collected along a transect orthogonal to the line coast $\left(38^{\circ} 15^{\prime} 46.66^{\prime \prime} \mathrm{N}-15^{\circ} 38^{\prime} 33.11^{\prime \prime} \mathrm{E}\right)$, in a vegetated rocky bottom characterized by patch distributed fleshy and calcareous red algae, at $15 \mathrm{~m}$ (3 specimens) and 26 $\mathrm{m}$ depth (2 specimens).

Outside of the type locality, two specimens (Figure 1) have been collected near Briatico (VV) $\left(38^{\circ} 43^{\prime} 37.65^{\prime \prime} \mathrm{N}\right.$ - $16^{\circ} 1$ '20.67"E), about $4 \mathrm{~m}$ depth, from a rocky substrate partially covered by Cystoseiracee brown algae (repository code: CWR147-3121A1-2).

In both type and new localities, $A$. scuderii was always found sympatric with the close congeneric A. scabra (Philippi, 1844).

Size ranged between $1.2 \mathrm{~mm}$ and $2.0 \mathrm{~mm}$ for Messina specimens and between $1.8 \mathrm{~mm}$ and $1.9 \mathrm{~mm}$ for Tyrrhenian specimens (Figure 1). 


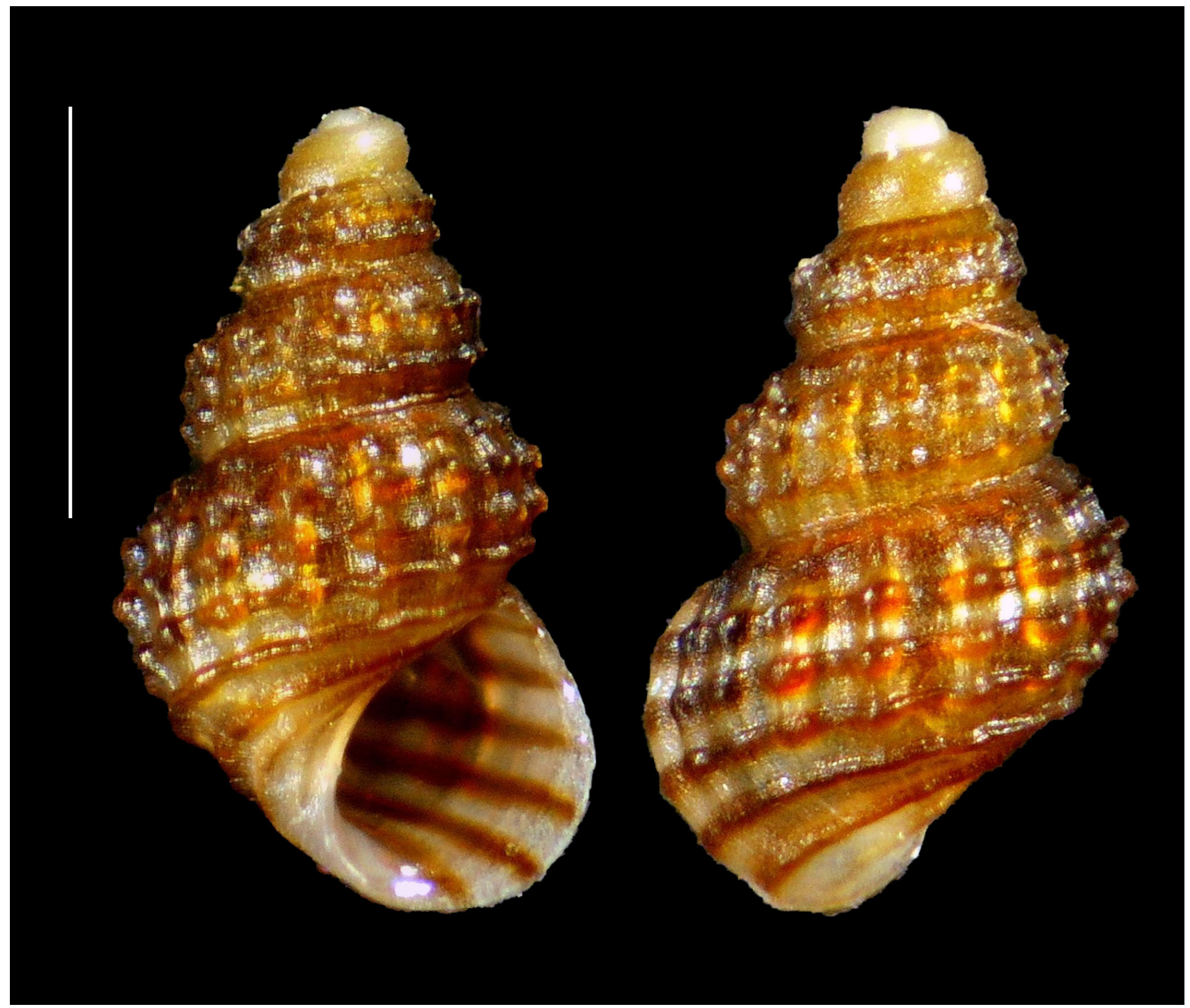

Figure 1. Ventral and dorsal view of a Alvania scuderii Villari, 2017 specimen from Briatico, South-eastern Tyrrhenian sea Scale bar: $1 \mathrm{~mm}$

The new records of $A$. scuderii provide further information about habitat and depth range of this rarely reported gastropod. The species, that Villari (2017) indicated as preferentially sciaphilous, colonizing both "rocky and very shallow waters, between algae on stones", in present investigation has been found associated to different typologies of photophilic algal covering and, deeper, to variously vegetated rocky bottoms. Depth range was wider than initially described, since the species occurs at least from $1 \mathrm{~m}$ to $26 \mathrm{~m}$ depth. Deeper records of living specimens, in general, agree with some reports of empty shells from Linosa, whilst dead specimen from 43-44 m depth, at Scilla (Amati et al., 2020), might be displaced from shallower rocky bottoms. Although poor information is available on the related mollusc assemblage, present data at least confirm that $A$. scuderii is normally sympatric with the close $A$. scabra, which is always more abundant, in agreement with Amati et al. (2020). 
The present records of $A$. scuderii (Figure 2), confirming the stable settlement of this species in the type locality, also expand northward the known areal, in the nearby Tyrrhenian basin. Such distribution, defining an almost continuous corridor, which connects the Tyrrhenian Calabrian coasts to the
Strait of Sicily, throughout the Strait of Messina and Ionian coasts of Sicily (Figure 2), might suggest an areal restricted to the eastern boundary of the western Mediterranean, as it is drawn in Bianchi \& Morri (2000), and in accordance with the local hydrology.



Figure 2. Alvania scuderii Villari, 2017 distribution. A -Strait of Messina (Type locality); B -San Giovanni Li Cuti; C - Linosa Island; D - Briatico (present record) 
Satellite thermography's, in fact, show a well distinct "cold strip" superimposed to the southern and eastern Sicily shelf, and overflowing into the southern Tyrrhenian sea through the Messina Strait (Bôhm et al., 1987), which determines a substantial continuity throughout the whole A. scuderii areal. Such coastal waters, that are colder than the close Ionian and Tyrrhenian typical water masses, have different origin, since southward they are tied to a wind-induced upwelling regime (Levi et al., 2003), whilst northward the effect of the Messina Strait tidal upwelling is recognizable (Bôhm et al., 1987). The records from the isle of Linosa, although concerning an area that is almost peripheral in respect to the core of such peculiar water-masses, can be explained by the Atlantic-Ionian Current pathway, one branch of which originates an anticiclonic gyre circling around Linosa, before flowing towards Sicily (Reyes Suarez et al., 2019). We may suppose, in agreement with Cuttitta et al. (2016), that mesoscale oceanographic structures play a key role in shaping the actual distribution of A. scuderii. This species, in fact, whose paucispiral protoconch indicates a non-planktotrophic larval development (Nützel, 2014), has a moderate dispersion capacity, on turn conditioned by the effectiveness of lateral supply and availability of neighboring steppingstones. In this respect, we suggest that $A$. scuderii might almost continuously occur throughout the completely southern and eastern coast of Sicily, up to a southeastern Tyrrhenian area which is still affected by the Strait of Messina tidal regime. Such distribution, whose effectiveness is however conditioned by the recent splitting of $A$. scabra in a rich species complex which includes A. scuderii (Amati et al., 2020), contributes to a patchiness of closely related species which together, but also individually ( $A$. scabra), cover the whole Mediterranean western basin.

\section{Conclusion}

The occurrence of $A$. scuderii, in particular, contributes to define a Mediterranean western-eastern biogeographic boundary line, which however cannot be considered as an ecotone, but as a front whose oceanographic features allow a WestMediterranean footprint more marked than in nearby Northwesternmost areas.

\section{Compliance with Ethical Standard}

Conflict of interests: The authors declare that for this article they have no actual, potential or perceived conflict of interests.

Ethics committee approval: Approved by institutional, regional and national animal ethical statements.

\section{Funding disclosure: -}

Acknowledgments: Many thanks to Danilo Scuderi who confirmed the specimens determination.

\section{Disclosure: -}

\section{References}

Amati, B., Appolloni, M., Giulio, A., Scuderi, D., Smriglio, C., Oliverio, M. (2020). Revision of the Recent Alvania scabra (Philippi, 1844) complex (Mollusca, Gastropoda, Rissoidae) from the Mediterranean Sea with the description of a new species. Zootaxa, 4767(3), 415-458.

http://dx.doi.org/10.11646/zootaxa.4767.3.3

Bianchi C.N., Morri, C. (2000). Marine biodiversity of the Mediterranean Sea: situation, problems and prospects for future research. Marine Pollution Bulletin, 40, 367-376. https://doi.org/10.1016/S0025-326X(00)00027-8

Bôhm E., Magazzu G., Wald L., Zoccolotti M.-L. (1987). Coastal currents on the Sicilian shelf south of Messina. Oceanologica Acta, 10(2), 137-142.

Cuttitta A., Quinci E.M., Patti B., Bonomo S., Bonanno A., Musco M., Torri M., Placenti F., Basilone G., Genovese S., Armeri G.M., Spanò A., Arculeo M., Mazzola A., Mazzola S. (2016). Different key roles of mesoscale oceanographic structures and ocean bathymetry in shaping larval fish distribution pattern: A case study in Sicilian waters in summer 2009. Journal of Sea Research, 115, 6-17. https://doi.org/10.1016/j.seares.2016.04.005

Levi D., Andreoli M.G., Bonanno A., Fiorentino F., Garofalo G., Mazzola S., Norrito G., Patti B., Pernice G., Ragonese S., Giusto G.B., Rizzo P. (2003). Embedding sea surface temperature anomalies into the stock recruitment relationship of red mullet (Mullus barbatus L. 1758) in the Strait of Sicily. Scientia Marina, 67(suppl. 1), 259-268. https://doi.org/10.3989/scimar.2003.67s1259

Nützel A. (2014). Larval ecology and morphology in fossilgastropods. Palaeontology, 57(3), 479-503.

https://doi.org/10.1111/pala.12104 
Reyes Suarez N.C., Cook M.S., Gačić M., D.J. Paduan, Drago A., Cardin V. (2019). Sea surface circulation structures in the Malta-Sicily channel from remote sensing data. Water, 11(1589), 1-19.

https://doi.org/10.3390/w11081589

Scaperrotta M., Bartolini S., Bogi C. (2019). Accrescimenti: stadi di accrescimento dei molluschi marini del Mediterraneo. Vol. 10. L'Informatore Piceno, Ancona, 212 pp.
Villari A., Scuderi D. (2017). Taxonomical notes on some poorly known mollusca species from the Strait of Messina (Italy). Biodiversity Journal, 8(1), 193-204.

Villari A. (2017). A new remarkable species of the Alvania scabra (Philippi, 1844) group from the Ionian Sea: $A$. scuderii n. sp. (Gastropoda, Rissoidae). Biodiversity Journal, 8(4), 937-942. 